Article

\title{
Effects of graphitic carbon nitride on the dehydrogenation of ammonia borane
}

\author{
ZHANG Jing, HE Teng * LIU Bin, LIU Lin, ZHAO Zelun, HU Daqiang, JU Xiaohua, WU Guotao, \\ CHEN Ping\#
}

Dalian Institute of Chemical Physics, Chinese Academy of Sciences, Dalian 116023, Liaoning, China

\section{A R T I C L E I I N F}

Article history:

Received 28 December 2012

Accepted 14 March 2013

Published 20 July 2013

Keywords:

Ammonia borane

Carbon nitride

Dehydrogenation

Lithium borohydride

\begin{abstract}
A B S T R A C T
By ball milling carbon nitride $\left(\mathrm{C}_{3} \mathrm{~N}_{4}\right)$ and ammonia borane $(\mathrm{AB})$, the $A B-\mathrm{C}_{3} \mathrm{~N}_{4}$ system was successfully synthesized. It is shown that the dehydrogenation temperature of the $A B-C_{3} N_{4}$ system was obviously decreased. However, the concentration of byproduct ammonia was much higher than that of pristine $\mathrm{AB}$. Thus, $\mathrm{LiBH}_{4}$-modified $\mathrm{C}_{3} \mathrm{~N}_{4}\left(\mathrm{LC}_{3} \mathrm{~N}_{4}\right)$ was produced and employed to synthesize a $\mathrm{AB}-\mathrm{LC}_{3} \mathrm{~N}_{4}$ system. The dehydrogenation of the $\mathrm{AB}-\mathrm{LC}_{3} \mathrm{~N}_{4}$ system was investigated using X-ray diffraction, temperature-programmed desorption-mass spectrometry, thermogravimetry-differential thermal analysis, and nuclear magnetic resonance. The results show that the dehydrogenation temperatures of the $\mathrm{AB}-\mathrm{LC}_{3} \mathrm{~N}_{4}$ systems were reduced to a lower region compared with pristine $\mathrm{AB}$. Moreover, byproduct borazine and the induction period were significantly suppressed. $\mathrm{After}_{\mathrm{LiBH}}$ modification on $\mathrm{C}_{3} \mathrm{~N}_{4}$, the other byproduct ammonia was also reduced in the dehydrogenation process. Dynamic analysis and NMR characterization results show that the decomposition mechanism of $\mathrm{AB}-\mathrm{LC}_{3} \mathrm{~N}_{4}$ still follows the self-decomposition of $\mathrm{AB}$, which is induced by the formation of $\mathrm{NH}_{3} \mathrm{BH}_{2} \mathrm{NH}_{3} \mathrm{BH}_{4}$.
\end{abstract}

(c) 2013, Dalian Institute of Chemical Physics, Chinese Academy of Sciences. Published by Elsevier B.V. All rights reserved.

\section{Introduction}

With the rapid development of global economy, the increasingly scarce fossil resource cannot meet the growing needs for energy. Due to the advantages of cleaning, abundance, high energy, and high efficiency, hydrogen as an energy carrier has been highly expected. However, developing highly efficient onboard hydrogen storage systems, as well as providing safe and reliable hydrogen sources for the vehicle fuel cell, is one of the bottlenecks on restricting the industrial application of hydrogen. It was found that the most effective and safest method for onboard hydrogen storage is to store the hydrogen in solid media, such as physical adsorption [1], metal hydride [2], and chemical hydride materials [3], etc. Ammonia borane (AB) has been paid great attention due to its high weight density (19.6 wt\%) and volume density (145 g/L) of hydrogen [4]. However, the disadvantages of this material are dehydrogenation at high temperature, producing poison byproducts (such as ammonia, borane, and borazine $\left.\left(\mathrm{N}_{3} \mathrm{~B}_{3} \mathrm{H}_{6}\right)\right)$, as well as sample foaming after dehydrogenation [4,5]. Based on these disadvantages, modifications on $\mathrm{AB}$ were made from the following aspects: dispersing $A B$ into the support with large surface area [6], using transition metal catalysts to catalyze the dehydrogenation [7,8], thermal decomposition in an ionic liquid [9], and

\footnotetext{
* Corresponding author. Tel: +86-411-84379583; Fax: +86-411-84379583; E-mail: heteng@dicp.ac.cn

\# Corresponding author. Tel: +86-411-84379905; Fax: +86-411-84379583; E-mail: pchen@dicp.ac.cn

This work was supported by the Knowledge Innovation Program of CAS (KJCX2-YW-H21) and the National Basic Research Program of China (973 Program, 2010CB631304). 
dehydrogenation catalyzed by acid-base catalysts [10]. These methods have certain positive effects on the dehydrogenation of $A B$, either decreasing the dehydrogenation temperature or suppressing the production of by-products. Even though, none of these methods could absolutely overcome the entire shortcomings. Neiner et al. [11] found that $\mathrm{AB}$ modified with nano boron nitride $(\mathrm{BN})$ can significantly decrease the dehydrogenation temperature, obviously reduce the induction period, and lower the exothermicity of hydrogen release. However, they also found that byproduct borazine increased obviously during dehydrogenation. Feaver et al. [12] dispersed AB into porous carbon cryogel to obtain a coherent carbon cryogel-ammonia borane composite, which significantly reduced the dehydrogenation temperature and activation energy during hydrogen release. Zhao et al. [13] synthesized a novel water-resistant material by confining $\mathrm{AB}$ in poly(methyl acrylate) (PMA). It efficiently lowered the dehydrogenation temperature and suppressed the production of borazine. Therefore, we can conclude that $\mathrm{C}$ - and $\mathrm{N}$-based materials can efficiently promote the dehydrogenation of $\mathrm{AB}$.

In this paper, we synthesized carbon nitride $\left(\mathrm{C}_{3} \mathrm{~N}_{4}\right)$ and modified $\mathrm{AB}$ with $\mathrm{C}_{3} \mathrm{~N}_{4}$. It is shown that adding $\mathrm{C}_{3} \mathrm{~N}_{4}$ can reduce the dehydrogenation temperature, accelerate the dehydrogenation rate, and suppress the generation of byproduct borazine. However, the $\mathrm{NH}_{3}$ concentration slightly increases during hydrogen release in $\mathrm{C}_{3} \mathrm{~N}_{4}$-modified $\mathrm{AB}$. Therefore, we further modified $\mathrm{C}_{3} \mathrm{~N}_{4}$ with $\mathrm{LiBH}_{4}$ and found that this can efficiently reduce the concentration of ammonia during dehydrogenation.

\section{Experimental}

\subsection{Preparation of $A B, C_{3} N_{4}$, and $x A B-y L C_{3} N_{4}$ composite system}

$\mathrm{AB}$ was synthesized using the method in the literature [14]. $\mathrm{C}_{3} \mathrm{~N}_{4}$ was prepared by modifying the method in Ref. [15]. Cyanamide (98\%, Alfa-Aesar, $2 \mathrm{~g}$ ) was heated under nitrogen flow up to $350{ }^{\circ} \mathrm{C}$ keeping for $3 \mathrm{~h}$, and then the temperature was increased to $390{ }^{\circ} \mathrm{C}$ keeping for $4 \mathrm{~h}$, then continually increased to $550^{\circ} \mathrm{C}$ keeping for $4 \mathrm{~h}$, and then cooled at room temperature. All the heating rates were $1{ }^{\circ} \mathrm{C} / \mathrm{min}$. The as-obtained yellow solid was $\mathrm{C}_{3} \mathrm{~N}_{4}$.

For the preparation of the $\mathrm{AB}$ and $\mathrm{LiBH}_{4}$-modified $\mathrm{C}_{3} \mathrm{~N}_{4}$

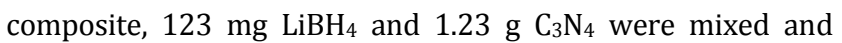
milled in a Planetary Ball Mills (Retsch, PM400) for $5 \mathrm{~h}$ (200 $\mathrm{r} / \mathrm{min}$ ). The mixture was treated under argon atmosphere at $300{ }^{\circ} \mathrm{C}$ for $2 \mathrm{~h}$. The obtained $\mathrm{LiBH}_{4}$-modified $\mathrm{C}_{3} \mathrm{~N}_{4}$ was named $\mathrm{LC}_{3} \mathrm{~N}_{4}$. Three $x \mathrm{AB}-y \mathrm{LC}_{3} \mathrm{~N}_{4}$ composite samples were obtained by milling the mixture of $\mathrm{AB}$ and $\mathrm{LC}_{3} \mathrm{~N}_{4}$ with mass ratios $(x: y)$ of $2: 1,1: 1$, and $1: 2$, respectively, for $24 \mathrm{~h}$.

\subsection{Dehydrogenation performance test of $A B, C_{3} N_{4}$, and $x A B-y L C_{3} N_{4}$}

A homemade temperature-programmed desorption-mass spectrometry (TPD-MS) combined system was employed to detect dehydrogenation of $\mathrm{AB}$ and $x \mathrm{AB}-y \mathrm{LC}_{3} \mathrm{~N}_{4}$. The sample was heated under argon at $2{ }^{\circ} \mathrm{C} / \mathrm{min}$ up to $400{ }^{\circ} \mathrm{C}$. The gaseous products from the dehydrogenation of $\mathrm{AB}$ and $x \mathrm{AB}-y \mathrm{LC}_{3} \mathrm{~N}_{4}$ were detected by an on-line mass spectrometer.

Volumetric release measurements of hydrogen desorption from samples were performed on a homemade apparatus. In a glove box, a certain amount of $\mathrm{AB}$ or $x \mathrm{AB}-y \mathrm{LC}_{3} \mathrm{~N}_{4}$ was weighted on the bottom of the reactor and sealed. The reactor was then put in a pre-heated furnace at $75{ }^{\circ} \mathrm{C}$. At the same time, the pressure sensor was turned on to detect the dehydrogenation process. The volume of hydrogen desorption was calculated based on the ideal gas equation.

After dehydrogenation, the gases were slowly imported to a prepared dilute sulphuric acid solution. By recording the variation of conductivity of the dilute sulphuric acid solution and the quantity of imported gases, the concentration of $\mathrm{NH}_{3}$ in the produced gases can be calculated.

\subsection{Characterization of $A B, C_{3} N_{4}$, and $x A B-y L C_{3} N_{4}$}

The crystal structures of $\mathrm{AB}, \mathrm{C}_{3} \mathrm{~N}_{4}$, and $x \mathrm{AB}-y \mathrm{LC}_{3} \mathrm{~N}_{4}$ were obtained on a PANalytical X-ray diffractometer (XRD) with $\mathrm{Cu}$ $K_{\alpha}$ radiation $(40 \mathrm{kV}, 40 \mathrm{~mA})$ in the range of $5^{\circ}-80^{\circ}$.

Thermogravimetry-differential thermal analysis (TG-DTA) measurements were conducted on an STA449C thermal analyzer (Netzsch). The samples were heated under purified argon at $2{ }^{\circ} \mathrm{C} / \mathrm{min}$ up to $400{ }^{\circ} \mathrm{C}$.

${ }^{11} \mathrm{~B}$ and ${ }^{13} \mathrm{C}$ MAS NMR measurements were carried out on a Bruker Avance 500 NMR spectrometer (11.7 T) with a frequency of 160.5 and $125.76 \mathrm{MHz}$, respectively. $\mathrm{LiBH}_{4}$ and glycine were used as chemical shift references.

\section{Results and discussion}

\subsection{Dehydrogenation performance test and characterization}

The synthesized $\mathrm{AB}$ and $\mathrm{C}_{3} \mathrm{~N}_{4}$ were mixed with the mass ratio of $1: 1$ and milled to obtain an $A B-C_{3} N_{4}$ sample. Figure 1 shows the TPD-MS spectra of pristine $A B$ and $A B-C_{3} N_{4}$. It can be seen that there are two steps for the dehydrogenation of $A B$

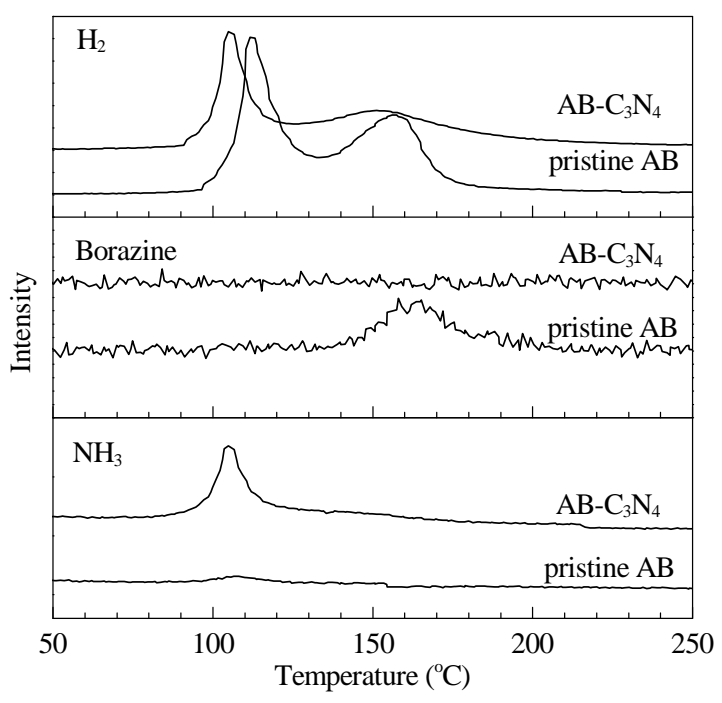

Fig. 1. TPD-MS curves of pristine $A B$ and $A B-C_{3} N_{4}$ samples. 
from room temperature to $250{ }^{\circ} \mathrm{C}$. The peak temperatures of desorption from $\mathrm{AB}$ are 112 and $160^{\circ} \mathrm{C}$, respectively, which are consistent with the literature $[4,5]$. However, the dehydrogenation temperature of $\mathrm{AB}-\mathrm{C}_{3} \mathrm{~N}_{4}$ in the first step decreases to 105 ${ }^{\circ} \mathrm{C}$, suggesting that adding $\mathrm{C}_{3} \mathrm{~N}_{4}$ can obviously promote the dehydrogenation of $\mathrm{AB}$. In the second step, the peak of dehydrogenation becomes broad and centers at $152{ }^{\circ} \mathrm{C}$. This broadening is probably caused by the formation of different decomposition products during $\mathrm{AB}-\mathrm{C}_{3} \mathrm{~N}_{4}$ dehydrogenation in the first step. It is worth noting that adding $\mathrm{C}_{3} \mathrm{~N}_{4}$ obviously suppressed the generation of byproduct borazine, which is harmful to fuel cells. However, the content of another byproduct, $\mathrm{NH}_{3}$, increased obviously. There might be a certain amount of $-\mathrm{NH}_{2}$ or -NH groups in synthesized $\mathrm{C}_{3} \mathrm{~N}_{4}$. During the interaction, these groups replace $\mathrm{NH}_{3}$ in $\mathrm{AB}$, which results in the increased $\mathrm{NH}_{3}$ content in the system. The elemental analysis results show that the composition of synthesized $\mathrm{C}_{3} \mathrm{~N}_{4}$ is $\mathrm{C}_{3} \mathrm{~N}_{5.4} \mathrm{H}_{0.2}$. The N-H vibrating peak at $3070-3310 \mathrm{~cm}^{-1}$ was also observed in the FT-IR spectrum of $\mathrm{C}_{3} \mathrm{~N}_{4}$, which further confirms the existence of $-\mathrm{NH}_{2}$ or -NH groups.

It was reported that hydride or borohydride can interact with amide, so that $\mathrm{NH}_{3}$ concentration can be reduced in gas productions during amide decomposition by adding hydride or borohydride $[3,16]$. In order to decrease the $\mathrm{NH}_{3}$ concentration in the dehydrogenation of $\mathrm{AB}-\mathrm{C}_{3} \mathrm{~N}_{4}$, we first synthesized $\mathrm{LC}_{3} \mathrm{~N}_{4}$ by modifying $\mathrm{C}_{3} \mathrm{~N}_{4}$ with $\mathrm{LiBH}_{4} . \mathrm{LC}_{3} \mathrm{~N}_{4}$ was then composited with $\mathrm{AB}$ through ball milling to obtain $x \mathrm{AB}-y \mathrm{LC}_{3} \mathrm{~N}_{4}$ with three different $\mathrm{AB}$ to $\mathrm{LC}_{3} \mathrm{~N}_{4}$ mass ratios, 2:1, 1:1, and 1:2, named as $2 \mathrm{AB}-1 \mathrm{LC}_{3} \mathrm{~N}_{4}, 1 \mathrm{AB}-1 \mathrm{LC}_{3} \mathrm{~N}_{4}$, and $1 \mathrm{AB}-2 \mathrm{LC}_{3} \mathrm{~N}_{4}$, respectively.

Figure 2 displays the XRD patterns of all the synthesized materials. There is a weak peak at $13.2^{\circ}$ shown in the XRD spectrum of $\mathrm{C}_{3} \mathrm{~N}_{4}$. The strongest peak is at $27.2^{\circ}$, which is attributed to the (002) reflection of $g-\mathrm{C}_{3} \mathrm{~N}_{4}$ [17]. The characteristic diffraction of $\mathrm{AB}$ appears in both of $1 \mathrm{AB}-1 \mathrm{LC}_{3} \mathrm{~N}_{4}$ and $2 \mathrm{AB}-1 \mathrm{LC}_{3} \mathrm{~N}_{4}$, which demonstrates that $\mathrm{AB}$ exists in the composites after ball milling. With reducing the content of $A B$, the intensity of the corresponding peak gradually decreased. Interestingly, it is found that around 1.2 equivalent gas/ $\mathrm{AB}$ are released from $1 \mathrm{AB}-2 \mathrm{LC}_{3} \mathrm{~N}_{4}$ after ball milling. The gas is mainly consisted of hydrogen and a small amount of $\mathrm{B}_{2} \mathrm{H}_{6}$ confirmed

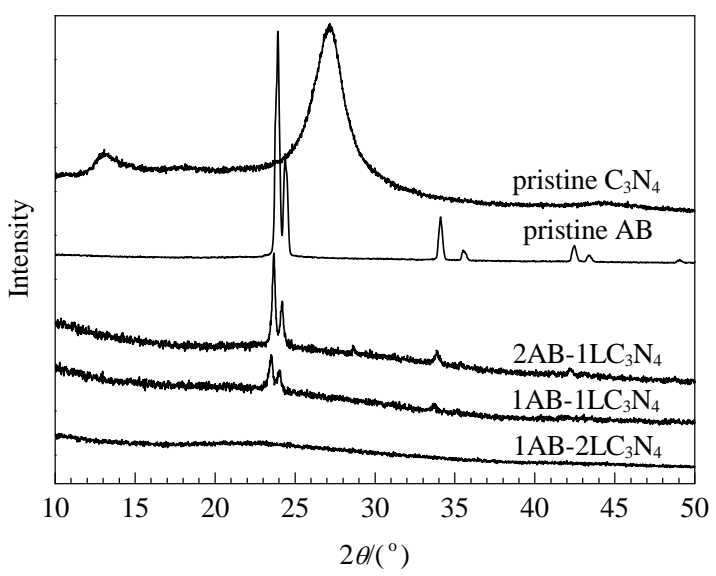

Fig. 2. XRD patterns of the as-prepared $C_{3} \mathrm{~N}_{4}$, pristine $A B, 2 A B-1 \mathrm{LC}_{3} \mathrm{~N}_{4}$, $1 \mathrm{AB}-1 \mathrm{LC}_{3} \mathrm{~N}_{4}$, and $1 \mathrm{AB}-2 \mathrm{LC}_{3} \mathrm{~N}_{4}$ samples.

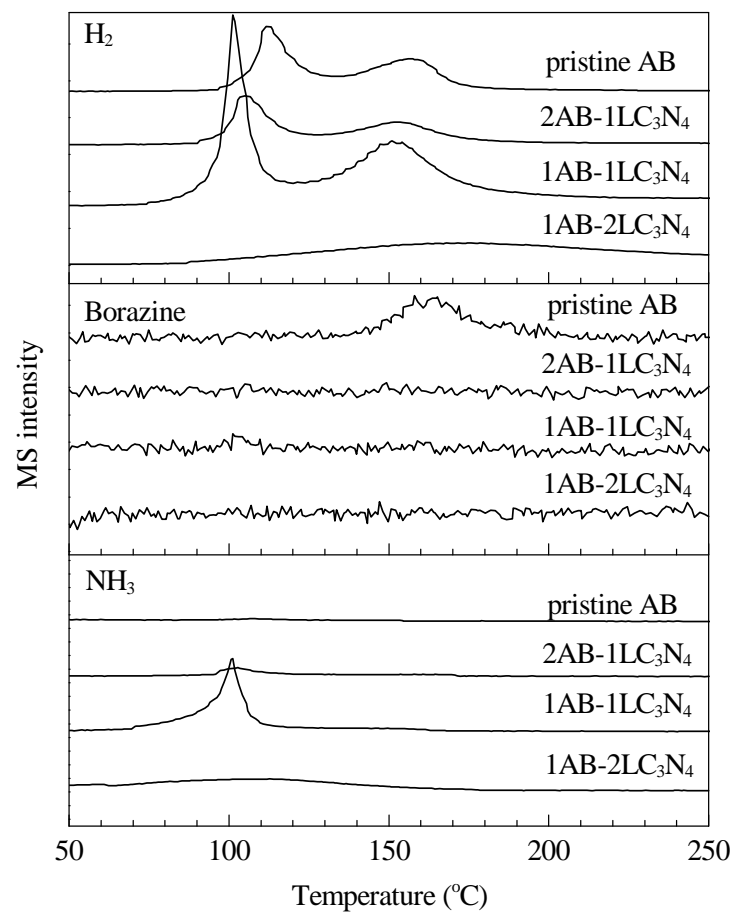

Fig. 3. TPD-MS curves of pristine $A B, 2 A B-1 L_{3} N_{4}, 1 A B-1 L_{3} N_{4}$, and $1 \mathrm{AB}-2 \mathrm{LC}_{3} \mathrm{~N}_{4}$ samples.

by MS. While, no gas was detected in the two other samples. All the reflections disappeared in the XRD spectrum of sample $1 \mathrm{AB}-2 \mathrm{LC}_{3} \mathrm{~N}_{4}$, which means that it presents amorphous state.

The dehydrogenation performance of the samples was detected by TPD-MS, which are shown in Fig. 3. In the first step, dehydrogenation temperature of $\mathrm{AB}, 2 \mathrm{AB}-1 \mathrm{LC}_{3} \mathrm{~N}_{4}$, and $1 \mathrm{AB}-1 \mathrm{LC}_{3} \mathrm{~N}_{4}$ is 112,105 , and $101{ }^{\circ} \mathrm{C}$, respectively. It is obvious that the dehydrogenation temperature decreases with increasing the content of $\mathrm{LC}_{3} \mathrm{~N}_{4}$. In addition, after modification by $\mathrm{LiBH}_{4}$, it is strengthened for $\mathrm{C}_{3} \mathrm{~N}_{4}$ promoting the dehydrogenation of $\mathrm{AB}$. It is worth mentioning that the addition of $\mathrm{LC}_{3} \mathrm{~N}_{4}$ also suppressed the generation of byproduct borazine. In the TPD-MS spectrum of $1 \mathrm{AB}-2 \mathrm{LC}_{3} \mathrm{~N}_{4}$, the signal of dehydrogenation almost disappeared, which is attributed to the hydrogen release during the ball milling process. Most importantly, compared with $\mathrm{AB}-\mathrm{C}_{3} \mathrm{~N}_{4}$, the content of $\mathrm{NH}_{3}$ produced during the dehydrogenation of $1 \mathrm{AB}-1 \mathrm{LC}_{3} \mathrm{~N}_{4}$ and $2 \mathrm{AB}-1 \mathrm{LC}_{3} \mathrm{~N}_{4}$ decreased significantly.

To detect the quantity of dehydrogenation, volumetric hydrogen release measurements were carried out at $75{ }^{\circ} \mathrm{C}$ (shown in Fig. 4). We found that the decomposition of $\mathrm{AB}$ at 75 ${ }^{\circ} \mathrm{C}$ has to experience an induction period and release 0.9 equivalents $\mathrm{H}_{2} / \mathrm{AB}$ within $12 \mathrm{~h}$, which is in good agreement with the DADB induction mechanism in $\mathrm{AB}$ self-decomposition [18]. Because hydrogen was released during the ball milling process, only a small amount of hydrogen was detected in the dehydrogenation of $1 \mathrm{AB}-2 \mathrm{LC}_{3} \mathrm{~N}_{4}$ at $75{ }^{\circ} \mathrm{C}$. In $1 \mathrm{AB}-1 \mathrm{LC}_{3} \mathrm{~N}_{4}$ and $2 \mathrm{AB}-1 \mathrm{LC}_{3} \mathrm{~N}_{4}$ systems, the induction period and dehydrogenation time were obviously shortened. It took $5.6 \mathrm{~h}$ for $\mathrm{AB}$ to release 0.6 equivalents $\mathrm{H}_{2} / \mathrm{AB}$, while to release the same amount of hydrogen, only $4.5 \mathrm{~h}$ and $3.4 \mathrm{~h}$ were needed for $1 \mathrm{AB}-1 \mathrm{LC}_{3} \mathrm{~N}_{4}$ 


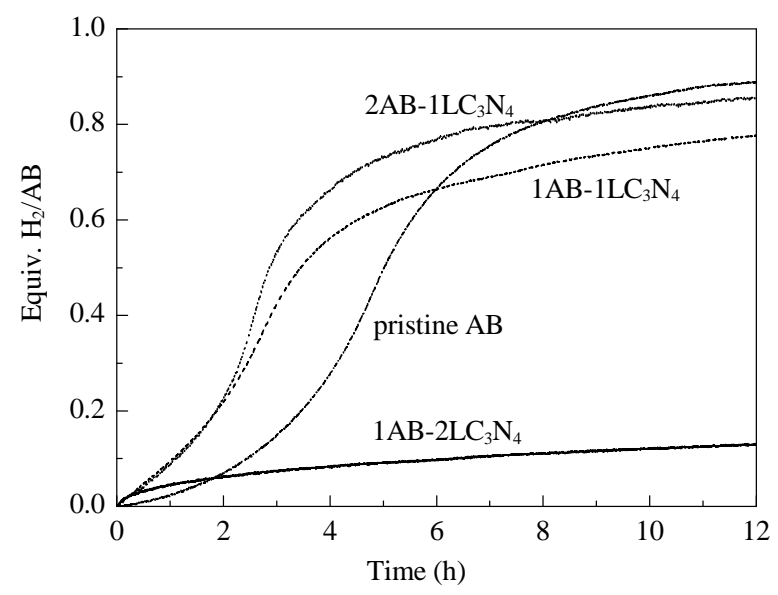

Fig. 4. Volumetric hydrogen release measurements at $75{ }^{\circ} \mathrm{C}$ on the pristine $\mathrm{AB}, 2 \mathrm{AB}-1 \mathrm{LC}_{3} \mathrm{~N}_{4}, 1 \mathrm{AB}-1 \mathrm{LC}_{3} \mathrm{~N}_{4}$, and $1 \mathrm{AB}-2 \mathrm{LC}_{3} \mathrm{~N}_{4}$ samples.

and $2 \mathrm{AB}-1 \mathrm{LC}_{3} \mathrm{~N}_{4}$, respectively. Although adding $\mathrm{LC}_{3} \mathrm{~N}_{4}$ can efficiently shorten the induction time during $\mathrm{AB}$ dehydrogenation, it is clear that the hydrogen release of $x \mathrm{AB}-y \mathrm{LC}_{3} \mathrm{~N}_{4}$ is keeping $\mathrm{S}$ type of curve. It means that the decomposition of $x \mathrm{AB}-y \mathrm{LC}_{3} \mathrm{~N}_{4}$ may still follow the DADB induction mechanism in the self-decomposition of $\mathrm{AB}$. In addition, as shown in Table 1, the concentrations of $\mathrm{NH}_{3}$ in $1 \mathrm{AB}-1 \mathrm{LC}_{3} \mathrm{~N}_{4}$ and $2 \mathrm{AB}-1 \mathrm{LC}_{3} \mathrm{~N}_{4}$ systems are $1.13 \%$ and $2.59 \%$, respectively, which are higher than that in $\mathrm{AB}$ but greatly lower than that in the $\mathrm{AB}-\mathrm{C}_{3} \mathrm{~N}_{4}$ system.

Figure 5 displays TG-DTA profiles of the samples. As shown, the first endothermic peak of $\mathrm{AB}$ is caused by the melting of $\mathrm{AB}$. The second exothermic peak is conduced to hydrogen release of $\mathrm{AB}$. The dehydrogenation temperature is $109{ }^{\circ} \mathrm{C}$, which is identical with the results of TPD. When $\mathrm{AB}$ was treated at 180 ${ }^{\circ} \mathrm{C}$, the mass loss is about $49.1 \%$, whereas $2 \mathrm{AB}-1 \mathrm{LC}_{3} \mathrm{~N}_{4}$ and $1 \mathrm{AB}-1 \mathrm{LC}_{3} \mathrm{~N}_{4}$ lost around $20.1 \%$ and $11.9 \%$ in mass, respectively. If calculated based on $\mathrm{AB}$, the mass of $2 \mathrm{AB}-1 \mathrm{LC}_{3} \mathrm{~N}_{4}$ and $1 \mathrm{AB}-1 \mathrm{LC}_{3} \mathrm{~N}_{4}$ lost $30.1 \%$ and $23.8 \%$, respectively. This means although more $\mathrm{NH}_{3}$ was produced in the $x \mathrm{AB}-y \mathrm{LC}_{3} \mathrm{~N}_{4}$ system, this system suppressed other byproducts (such as borazine) more efficiently. It is worth noting that no endothermic peak of $\mathrm{AB}$ melting was detected in $2 \mathrm{AB}-1 \mathrm{LC}_{3} \mathrm{~N}_{4}$ and $1 \mathrm{AB}-1 \mathrm{LC}_{3} \mathrm{~N}_{4}$ systems. Because adding $\mathrm{LC}_{3} \mathrm{~N}_{4}$ can decrease the dehydrogenation temperature of $\mathrm{AB}$, the dehydrogenation temperatures of $2 \mathrm{AB}-1 \mathrm{LC}_{3} \mathrm{~N}_{4}$ and $1 \mathrm{AB}-1 \mathrm{LC}_{3} \mathrm{~N}_{4}$ may below the melting pointing, which damages the crystal structure of $\mathrm{AB}$ before melting.

After decomposition, $\mathrm{AB}$ turns to be an amorphous material. Any structure information from an XRD pattern cannot be obtained. Thus, this paper characterized and modified $A B$ using NMR technique. Figure 6 and Figure 7 display the ${ }^{11} \mathrm{~B}$ and ${ }^{13} \mathrm{C}$ MAS NMR spectra of all the samples before and after decomposition. As shown in Fig. 6, the resonance at -26.7 is the typical signal of $\mathrm{BH}_{3}$ in $\mathrm{AB}$ [19]. After modification by $\mathrm{LiBH}_{4}$, two $\mathrm{B}$ species in $\mathrm{C}_{3} \mathrm{~N}_{4}$ appeared, with the chemical shift of 16.9 and

\section{Table 1}

$\mathrm{NH}_{3}$ concentration in the gaseous products after dehydrogenation at 75 ${ }^{\circ} \mathrm{C}$ on the samples.

\begin{tabular}{lcccc}
\hline Sample & Pristine $\mathrm{AB}$ & $2 \mathrm{AB}-1 \mathrm{LC}_{3} \mathrm{~N}_{4}$ & $1 \mathrm{AB}-1 \mathrm{LC} \mathrm{N}_{3} \mathrm{~N}_{4}$ & $1 \mathrm{AB}-1 \mathrm{C}_{3} \mathrm{~N}_{4}$ \\
\hline$c\left(\mathrm{NH}_{3}\right) / \%$ & 0.14 & 2.59 & 1.13 & 5.51 \\
\hline
\end{tabular}

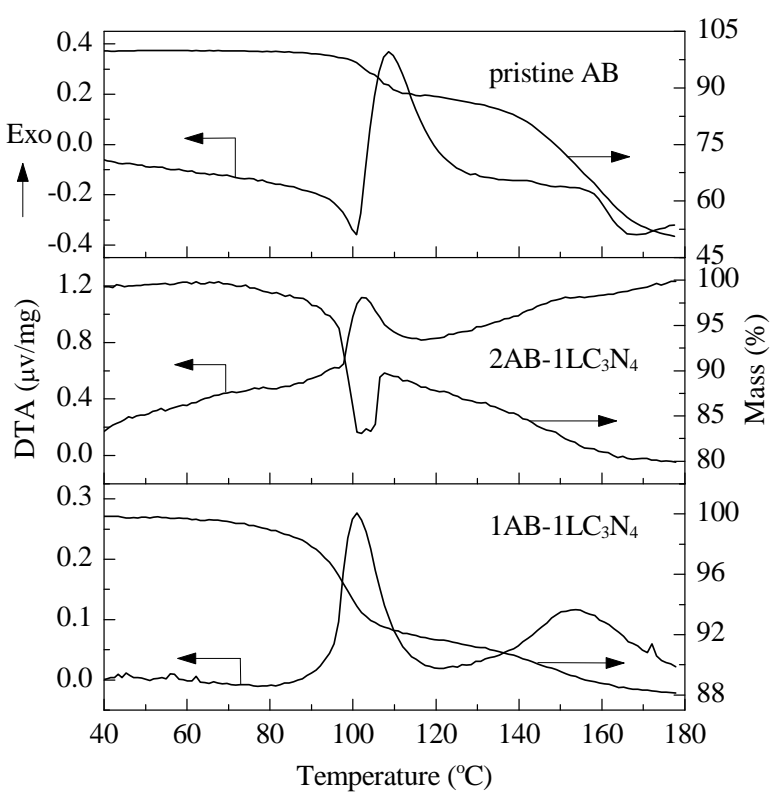

Fig. 5. TG-DTA curves of pristine $A B, 2 A B-1 L_{3} N_{4}$, and $1 A B-1 L_{3} N_{4}$ samples.

-0.4 . The former is attributed to $s p^{2}-\mathrm{BN}_{3}$ or $\mathrm{BN}_{2} \mathrm{H}$ species. The latter is probably related to N-B-C species formed by the interaction of $\mathrm{LiBH}_{4}$ and $\mathrm{C}_{3} \mathrm{~N}_{4}$. In the spectra of ball milled $2 \mathrm{AB}-1 \mathrm{LC}_{3} \mathrm{~N}_{4}$ and $1 \mathrm{AB}-1 \mathrm{LC}_{3} \mathrm{~N}_{4}$ systems, besides a $\mathrm{BH}_{3}$ signal, the characteristic resonance of $\mathrm{BH}_{4}^{-}$was also detected at -41.5 , which is probably produced from decomposition of $\mathrm{AB}$ induced by $\mathrm{LC}_{3} \mathrm{~N}_{4}$. After hydrogen release at $75{ }^{\circ} \mathrm{C}$, a small amount of $\mathrm{BH}_{3}$ still existed in $\mathrm{AB}$. In addition, new resonances at -36.5 and -10.1 appeared, corresponding to $\mathrm{BH}_{4}$ and $\mathrm{BH}_{2}$, respectively, which can be attributed to the formation of DADB [20]. It is worth noting that the chemical shift of $\mathrm{BH}_{4}$, formed by $\mathrm{AB}$ dehydrogenation, is around -36.5 , which is different from the $2 \mathrm{AB}-1 \mathrm{LC} \mathrm{C}_{3} \mathrm{~N}_{4}$ and $1 \mathrm{AB}-1 \mathrm{LC}_{3} \mathrm{~N}_{4}$ systems (shown in Fig. 6). In the 11B MAS NMR spectrum of $2 \mathrm{AB}-1 \mathrm{LC}_{3} \mathrm{~N}_{4}$ after hydrogen release at $75{ }^{\circ} \mathrm{C}$, the peaks at $-22.2,-40.4$, and -35.5 can be observed, which are related to the residual of $\mathrm{BH}_{3}, \mathrm{BH}_{4}$ from $\mathrm{LC}_{3} \mathrm{~N}_{4}$ in-

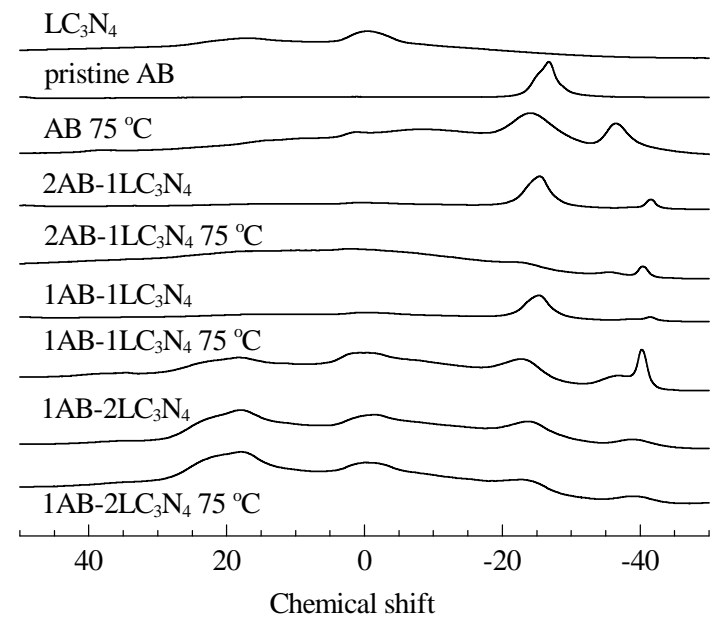

Fig. 6. ${ }^{11} \mathrm{~B}$ MAS NMR spectra of $\mathrm{LC}_{3} \mathrm{~N}_{4}$, pristine $\mathrm{AB}, 2 \mathrm{AB}-1 \mathrm{LC}_{3} \mathrm{~N}_{4}$, $1 \mathrm{AB}-1 \mathrm{LC}_{3} \mathrm{~N}_{4}$, and $1 \mathrm{AB}-2 \mathrm{LC}_{3} \mathrm{~N}_{4}$ samples and the dehydrogenated samples at $75^{\circ} \mathrm{C}$. 


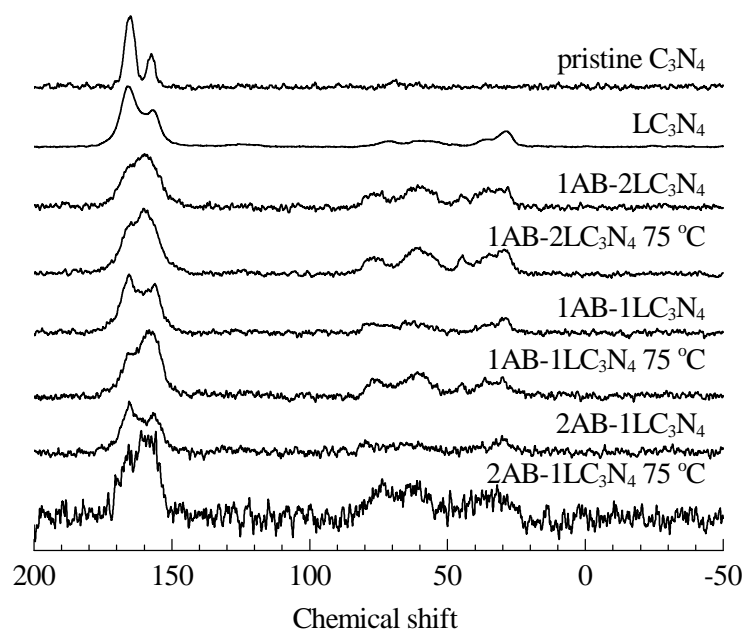

Fig. 7. ${ }^{13} \mathrm{C}$ MAS NMR spectra of $\mathrm{C}_{3} \mathrm{~N}_{4}, \mathrm{LC}_{3} \mathrm{~N}_{4}, 1 \mathrm{AB}-2 \mathrm{LC}_{3} \mathrm{~N}_{4}, 1 \mathrm{AB}-1 \mathrm{LC}_{3} \mathrm{~N}_{4}$, and $2 \mathrm{AB}-1 \mathrm{LC}_{3} \mathrm{~N}_{4}$ samples and the dehydrogenated samples at $75{ }^{\circ} \mathrm{C}$.

duced $\mathrm{AB}$ decomposition, and $\mathrm{BH}_{4}$ from $\mathrm{AB}$ self-decomposition, respectively. The broad peak in the range from -26 to 30 is probably due to the signals of $\mathrm{BH}_{3}, \mathrm{BH}_{2}, \mathrm{BH}\left(s p^{3}\right), \mathrm{BN}_{2} \mathrm{H}\left(s p^{2}\right)$ or $\mathrm{BN}_{3}\left(s p^{2}\right)$, and N-B-C species [21]. Because hydrogen release happened during ball milling, we got similar spectra of $1 \mathrm{AB}-2 \mathrm{LC}_{3} \mathrm{~N}_{4}$ before and after treatment at $75^{\circ} \mathrm{C}$, which is also similar to the spectrum of $1 \mathrm{AB}-1 \mathrm{LC}_{3} \mathrm{~N}_{4}$ after dehydrogenation at $75{ }^{\circ} \mathrm{C}$, with the signals at $-40.3\left(\mathrm{BH}_{4}\right),-22.8\left(\mathrm{BH}_{3}\right),-1.2$ $(\mathrm{N}-\mathrm{B}-\mathrm{C})$, and $17.8\left(\mathrm{BN}_{2} \mathrm{H}\right.$ or $\left.\mathrm{BN}_{3}\right)$. In addition, high baseline in the range from 30 to -30 can be observed in these three spectra, which might be due to the existence of $\mathrm{BH}$ and $\mathrm{BH}_{2}$ species produced by $\mathrm{AB}$ decomposition. Because $\mathrm{BH}_{4}$ and $\mathrm{BH}_{2}$ species were observed in the productions of hydrogen release, we can deduce that the decomposition of $x \mathrm{AB}-y \mathrm{LC}_{3} \mathrm{~N}_{4}$ may still follow the DADB induction mechanism, which is consistent with the aforementioned $\mathrm{S}$ type hydrogen release curve.

The ${ }^{13} \mathrm{C}$ MAS NMR spectrum of $\mathrm{C}_{3} \mathrm{~N}_{4}$ (Fig. 7) exhibits two signals centered at 157 and 165, which are attributed to $\mathrm{CN}_{2}\left(\mathrm{NH}_{x}\right)$ (boundary of the loop) and $\mathrm{CN}_{3}$ (inner of the loop), respectively [21]. These typical signals are also observed in the ${ }^{13} \mathrm{C}$ MAS NMR spectra of $\mathrm{LC}_{3} \mathrm{~N}_{4}$ samples. Compared with $\mathrm{C}_{3} \mathrm{~N}_{4}$, the intensity of the peak at 157 increased. This indicates that due to the effect of $\mathrm{LiBH}_{4}$, the boundary carbon species in $\mathrm{C}_{3} \mathrm{~N}_{4}$ enhanced. Partial condensed rings in $\mathrm{C}_{3} \mathrm{~N}_{4}$ were probably split to single ring by $\mathrm{LiBH}_{4}$. In addition, there are several signals in the range of 23-83 shown in the spectrum of the $\mathrm{LC}_{3} \mathrm{~N}_{4}$ sample, which are attributed to $s p^{3}$-hybridized carbon atoms. After the condensed rings in $\mathrm{C}_{3} \mathrm{~N}_{4}$ split, the carbon atoms turned from $\mathrm{CN}_{3}$ ( $s p^{2}$-hybridized) to $\mathrm{CN}_{3} \mathrm{H}$ ( $s p^{3}$-hybridized) through further hydrogenation. In the ${ }^{13} \mathrm{C}$ MAS NMR spectra of $2 \mathrm{AB}-1 \mathrm{LC}_{3} \mathrm{~N}_{4}$, $1 \mathrm{AB}-1 \mathrm{LC}_{3} \mathrm{~N}_{4}$, and $1 \mathrm{AB}-2 \mathrm{LC}_{3} \mathrm{~N}_{4}$ before and after dehydrogenation, the characteristic peaks at 157 and 165 also exist. With the processing of dehydrogenation, the intensity of the peak at 165 obviously decreased, while that at 157 increased. This demonstrates that $\mathrm{AB}$ caused $\mathrm{C}_{3} \mathrm{~N}_{4}$ to change from condensed ring to single ring species, which results in the increase of carbon species on the boundary of the loop.

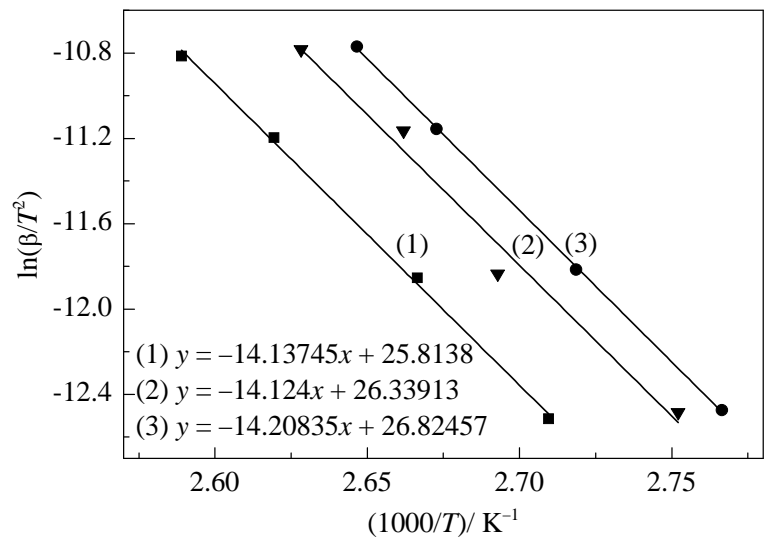

Fig. 8. Kissinger plots of the pristine $A B(1), 2 A B-1 L_{3} \mathrm{~N}_{4}$ (2), and $1 \mathrm{AB}-1 \mathrm{LC}_{3} \mathrm{~N}_{4}(3)$ samples at different heating rates.

\subsection{Kinetic analyses}

To obtain the information about the dehydrogenation kinetics of $\mathrm{AB}$ and modified $\mathrm{AB}$, this paper performed differential thermal analysis (DTA) at different heating rates to get the temperature at the maximum reaction rate. The pre-exponential factor and the activation energy $E_{\mathrm{a}}$ of $\mathrm{AB}$, $1 \mathrm{AB}-1 \mathrm{LC}_{3} \mathrm{~N}_{4}$, and $2 \mathrm{AB}-1 \mathrm{LC}_{3} \mathrm{~N}_{4}$ can be determined based on the Kissinger equation:

$$
\ln \left(\beta / T_{\mathrm{p}}^{2}\right)=\ln \left(A R / E_{\mathrm{a}}\right)-E_{\mathrm{a}} / R T_{\mathrm{p}}
$$

where $\beta$ is the heating rate, $T_{\mathrm{p}}$ is the temperature at which the maximum reaction rate peaks, and $R$ is the gas constant. Within the small range of temperature variation, $E_{\mathrm{a}}$ and $A$ are assumed to be constant. The dependence of $\ln \left(\beta / T_{\mathrm{p}}{ }^{2}\right)$ vs $1 / T_{\mathrm{p}}$ was plotted in Fig. 8. After simulation, a straight line was obtained, in which the slope represents $-E_{\mathrm{a}} / R$, and the intercept is $\ln \left(A R / E_{\mathrm{a}}\right)$. Then, $E_{\mathrm{a}}$ and $A$ can be calculated. Then the specific rate constant $k$ at a given temperature can be determined by the Arrhenius equation:

$$
k=A \exp \left(-E_{\mathrm{a}} / R T\right)
$$

Table 2 presents $E_{\mathrm{a}}, A$, and $k$ (at $75^{\circ} \mathrm{C}$ ) for each sample. It is clear that the activation energy of the first dehydrogenation step remains the same, which indicates that the mechanism of $x \mathrm{AB}-y \mathrm{LC}_{3} \mathrm{~N}_{4}$ hydrogen release may be the same as that of $\mathrm{AB}$ self-decomposition. It is consistent with the dehydrogenation curve and NMR results. This demonstrates that adding $\mathrm{LC}_{3} \mathrm{~N}_{4}$ can induce $\mathrm{AB}$ to quickly produce $\mathrm{DADB}$ at low temperature, which then induces the decomposition of $\mathrm{AB}$. Thus, the induction period of $\mathrm{AB}$ decomposition is shortened. According to the Arrhenius equation, the reaction rates of $2 \mathrm{AB}-1 \mathrm{LC}_{3} \mathrm{~N}_{4}$ and $1 \mathrm{AB}-1 \mathrm{LC}_{3} \mathrm{~N}_{4}$ in the first dehydrogenation step at $75^{\circ} \mathrm{C}$ are 1.8 and 2.3 times that of $\mathrm{AB}$. It is obvious that the hydrogen release rate is enhanced.

Table 2

$E_{\mathrm{a}}, A$, and $k$ (at $75{ }^{\circ} \mathrm{C}$ ) calculated from the Kissinger equation and Arrhenius equation.

\begin{tabular}{lccc}
\hline Sample & $E_{\mathrm{a}} /(\mathrm{kJ} / \mathrm{mol})$ & $A / \mathrm{min}^{-1}$ & $k / \mathrm{min}^{-1}$ \\
\hline $\mathrm{AB}$ & 117.5 & $2.30 \times 10^{15}$ & $5.32 \times 10^{-3}$ \\
$2 \mathrm{AB}-1 \mathrm{LC}_{3} \mathrm{~N}_{4}$ & 117.4 & $3.88 \times 10^{15}$ & $9.34 \times 10^{-3}$ \\
$1 \mathrm{AB}-1 \mathrm{LC}_{3} \mathrm{~N}_{4}$ & 118.1 & $6.34 \times 10^{15}$ & $1.20 \times 10^{-2}$ \\
\hline
\end{tabular}




\title{
Graphical Abstract
}

Chin. J. Catal., 2013, 34: 1303-1311 doi: 10.1016/S1872-2067(12)60566-X

\section{Effects of graphitic carbon nitride on the dehydrogenation of ammonia borane}

ZHANG Jing, HE Teng*, LIU Bin, LIU Lin, ZHAO Zelun, HU Daqiang, JU Xiaohua, WU Guotao, CHEN Ping* Dalian Institute of Chemical Physics, Chinese Academy of Sciences

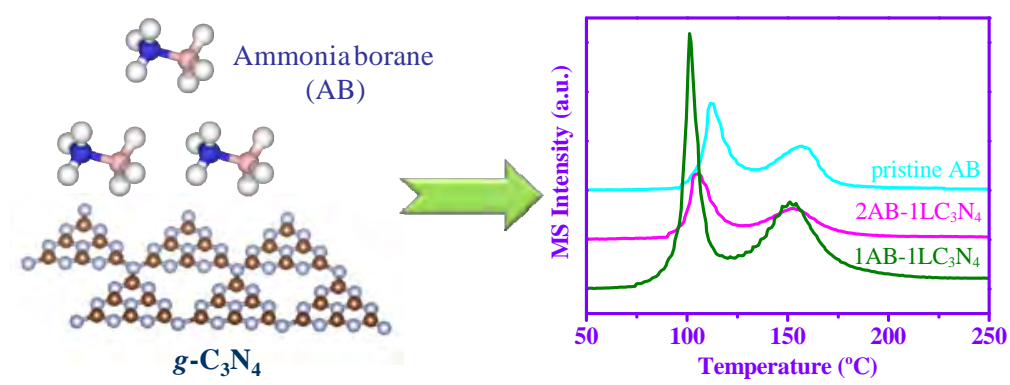

The dehydrogenation temperature of $\mathrm{C}_{3} \mathrm{~N}_{4}$-modified ammonia borane was reduced to lower region with depression of byproduct and induction period compared with pristine ammonia borane.

\section{Conclusions}

By modification of synthesized $\mathrm{C}_{3} \mathrm{~N}_{4}$ with $\mathrm{LiBH}_{4}, \mathrm{LC}_{3} \mathrm{~N}_{4}$ was obtained and was then used to modify $\mathrm{AB}$ to get excellent dehydrogenation materials. This study provides new ideas to improve the dehydrogenation performance of AB. However, a large amount of ammonia was produced during the dehydrogenation of modified $\mathrm{AB}$. Two aspects can be made to optimize the dehydrogenation of $\mathrm{AB}$ : (1) optimizing the synthesis method of $\mathrm{C}_{3} \mathrm{~N}_{4}$ to enhance the polymerization degree of $\mathrm{C}_{3} \mathrm{~N}_{4}$ and decrease the number of $\mathrm{NH}_{2}$ group in $\mathrm{C}_{3} \mathrm{~N}_{4}$; (2) adding other type of materials and shielding the $\mathrm{NH}_{2}$ group in $\mathrm{C}_{3} \mathrm{~N}_{4}$ to suppress the production of ammonia during the decomposition of AB.

\section{References}

[1] Rosi N L, Eckert J, Eddaoudi M, Vodak D T, Kim J, O'keeffe M, Yaghi O M. Science, 2003, 300: 1127

[2] Bogdanović B, Schwickardi M. J Alloys Compd, 1997, 253-254: 1

[3] Chen P, Xiong Z T, Luo J Z, Lin J Y, Tan K L. Nature, 2002, 420: 302

[4] Wolf G, Baumann J, Baitalow F, Hoffmann F P. Thermochim Acta, 2000, 343: 19

[5] Hu M G, Geanangel R A, Wendlandt W W. Thermochim Acta, 1978, 23: 249

[6] Gutowska A, Li L, Shin Y, Wang C M, Li X S, Linehan J C, Smith R S, Kay B D, Schmid B, Shaw W, Gutowski M, Autrey T. Angew Chem, Int Ed, 2005, 44: 3578
[7] He T, Xiong Z T, Wu G T, Chu H L, Wu C Z, Zhang T, Chen P. Chem Mater, 2009, 21: 2315

[8] Denney M C, Pons V, Hebden T J, Heinekey D M, Goldberg K I. J Am Chem Soc, 2006, 128: 12048

[9] Bluhm M E, Bradley M G, Butterick R III, Kusari U, Sneddon L G. J Am Chem Soc, 2006, 128: 7748

[10] Stephens F H, Baker R T, Matus M H, Grant D J, Dixon D A. Angew Chem, Int Ed, 2007, 46: 746

[11] Neiner D, Luedtke A, Karkamkar A, Shaw W, Wang J L, Browning N D, Autrey T, Kauzlarich S M. J Phys Chem C, 2010, 114: 13935

[12] Feaver A, Sepehri S, Shamberger P, Stowe A, Autrey T, Cao G Z.J Phys Chem B, 2007, 111: 7469

[13] Zhao J Z, Shi J F, Zhang X W, Cheng F Y, Liang J, Tao Z L, Chen J. Adv Mater, 2010, 22: 394

[14] Ramachandran P V, Gagare P D. Inorg Chem, 2007, 46: 7810

[15] Wang Y, Yao J, Li H R, Su D S, Antonietti M. J Am Chem Soc, 2011, 133: 2362

[16] Pinkerton F E, Meisner G P, Meyer M S, Balogh M P, Kundrat M D.J Phys Chem B, 2005, 109: 6

[17] Matsumoto S, Xie E Q, Izumi F. Diamond Relat Mater, 1999, 8: 1175

[18] Heldebrant D J, Karkamkar A, Hess N J, Bowden M, Rassat S, Zheng F, Rappe K, Autrey T. Chem Mater, 2008, 20: 5332

[19] Kang X D, Fang Z Z, Kong L Y, Cheng H M, Yao X D, Lu G Q, Wang P. Adv Mater, 2008, 20: 2756

[20] Stowe A C, Shaw W J, Linehan J C, Schmid B, Autrey T. Phys Chem Chem Phys, 2007, 9: 1831

[21] Jürgens B, Irran E, Senker J, Kroll P, Müller H, Schnick W. J Am Chem Soc, 2003, 125: 10288

[22] Jürgens B. [PhD Dissertation]. Munich: University of Munich (Germany), 2004

\section{石墨型氮化碳对氨硼烷放氢性能的影响}

\author{
张 静, 何 腾*, 刘 涁, 柳 林, 赵泽伦, 胡大强, 鞠晓花, 吴国涛, 陈 萍 \\ 中国科学院大连化学物理研究所, 辽宁大连116023
}

摘要: 利用石墨型氮化碳 $\left(\mathrm{C}_{3} \mathrm{~N}_{4}\right)$ 和氨嗍烷 $\left(\mathrm{NH}_{3} \mathrm{BH}_{3}, \mathrm{AB}\right)$ 球磨制备了 $\mathrm{AB}-\mathrm{C}_{3} \mathrm{~N}_{4}$ 体系, 发现 $\mathrm{C}_{3} \mathrm{~N}_{4}$ 的加入使 $\mathrm{AB}$ 放氢反应温度明显降低, 但是副产物氨气浓度有所升高. 因此, 利用 $\mathrm{LiBH}_{4}$ 改性的 $\mathrm{C}_{3} \mathrm{~N}_{4}\left(\mathrm{LC}_{3} \mathrm{~N}_{4}\right)$ 同 $\mathrm{AB}$ 球磨合成出了 $\mathrm{AB}-\mathrm{LC}_{3} \mathrm{~N}_{4}$ 体系, 并采用 $\mathrm{X}$ 射线衍射、程序 
升温脱附-质谱联用、热重-差热分析及核磁共振等技术考察了该体系的脱氢性能. 结果表明, 由于 $\mathrm{LC}_{3} \mathrm{~N}_{4}$ 的加入, $\mathrm{AB}$ 的放氢反应温 度明显降低, 放氢反应速率加快, 放氢诱导期缩短, 同时抑制了副产物无机苯的生成. 另外, $\mathrm{C}_{3} \mathrm{~N}_{4}$ 的化学修饰也降低了 $\mathrm{AB}-\mathrm{LC}_{3} \mathrm{~N}_{4}$ 放氢过程中生成氨气的浓度. 动力学分析和核磁共振结果表明, $\mathrm{AB}-\mathrm{LC}_{3} \mathrm{~N}_{4}$ 分解过程依然遵循 $\mathrm{NH}_{3} \mathrm{BH}_{2} \mathrm{NH}_{3} \mathrm{BH}_{4}$ 诱导的氨硼烷自分 解机理.

关键词: 氨硼烷; 氮化碳; 脱氢; 嗍氢化锂

收稿日期: 2012-12-28. 接受日期: 2013-03-14. 出版日期: 2013-07-20.

*通讯联系人. 电话: (0411)84379583; 传真: (0411)84379583; 电子信箱: heteng@dicp.ac.cn

\#通讯联系人. 电话: (0411)84379905; 传真: (0411)84379583; 电子信箱: pchen@dicp.ac.cn

基金来源：中国科学院知识创新工程(KJCX2-YW-H21); 国家重点基础研究发展计划(973计划, 2010CB631304).

本文的英文电子版由Elsevier出版社在ScienceDirect上出版(http://www.sciencedirect.com/science/journal/18722067).

\section{1. 前言}

随着世界经济的迅速发展, 日益紧缺的化石能源已 经不能够满足人们对能源与日俱增的需求. 氢能作为来 源广、能量高、洁净高效的二次能源, 被人们寄予厚望. 然而, 开发高效的车载储氢系统, 为车载燃料电池提供 安全可靠的氢源是制约氢能规模化应用的瓶颈之一. 研 究发现, 最安全有效的车载储氢方法是将氢气储存于固 体介质, 比如物理吸附材料 ${ }^{[1]} 、$ 金属氢化物 ${ }^{[2]}$ 和化学氢化 物 ${ }^{[3]}$ 等材料中. 氨硼烷 $\left(\mathrm{NH}_{3} \mathrm{BH}_{3}, \mathrm{AB}\right)$ 以其较高的储氢质 量密度(19.6 wt\%)和体积密度(145 g/L)而备受关注 ${ }^{[4]}$, 但 其放氢温度高, 可产生毒副产物(如氨气、嗍烷和无机苯 等), 且材料放氢后体积膨胀 ${ }^{[4,5]}$. 基于此, 研究人员从以 下几个方面对其进行了修饰改性: 将 $\mathrm{AB}$ 分散到大比表 面积的载体上 ${ }^{[6]}$, 或利用过渡金属催化剂催化放氢 ${ }^{[7,8]}$, 或在离子液体中热分解 ${ }^{[9]}$, 或利用酸碱催化剂催化放 氢 ${ }^{[10]}$. 这些方法对 $\mathrm{AB}$ 放氢性能都有一定的促进作用, 或 降低了脱氢温度, 或抑制了副产物的生成, 但没有任何 一种改性方法可以完全克服其缺点. Neiner等 ${ }^{[11]}$ 利用纳 米氮化硼 $(\mathrm{BN})$ 与 $\mathrm{AB}$ 进行复合, 发现其放氢温度显著降 低, 诱导期明显缩短, 放氢热效应减弱, 但是放氢气体中 副产物无机苯明显增多. 而Feaver等 ${ }^{[12]}$ 将 $\mathrm{AB}$ 分散在碳 凝胶上, 所得复合物有效降低了 $\mathrm{AB}$ 的放氢温度, 减小了 $A B$ 放氢过程中的活化能. Zhao 等 ${ }^{[13]}$ 将AB包裹到聚丙烯 酸甲酯材料中, 得到了一种抗水的新材料, 并且该材料 有效地降低了 $\mathrm{AB}$ 的放氢温度, 同时能够抑制副产物无 机苯的生成. 由此可见, $\mathrm{C}$ 基、 $\mathrm{N}$ 基材料可以有效提高 $\mathrm{AB}$ 的放氢性能.

本文自行合成了氮化碳 $\left(\mathrm{C}_{3} \mathrm{~N}_{4}\right)$, 并用它对 $A B$ 进行改 性. 结果表明, $\mathrm{C}_{3} \mathrm{~N}_{4}$ 的加入不仅降低了 $\mathrm{AB}$ 的脱氢反应温 度, 加快了脱氢反应速率, 而且抑制了杂质气体无机苯 的生成, 但放氢过程中 $\mathrm{NH}_{3}$ 含量有所增加. 因此, 我们利 用 $\mathrm{LiBH}_{4}$ 对 $\mathrm{C}_{3} \mathrm{~N}_{4}$ 进行了改性, 发现改性后的 $\mathrm{C}_{3} \mathrm{~N}_{4}$ 可以有
效降低脱氢反应气体中的 $\mathrm{NH}_{3}$ 浓度.

\section{2. 实验部分}

\section{1. $\mathrm{AB}, \mathrm{C}_{3} \mathrm{~N}_{4}$ 及 $x \mathrm{AB}-y \mathrm{LC} \mathrm{C}_{3} \mathrm{~N}_{4}$ 复合体系的制备}

按照文献[14]合成AB. $C_{3} \mathrm{~N}_{4}$ 按照改进的文献[15]的 方法制备, 具体操作如下：称取 $2 \mathrm{~g}$ 单氧胺 $(98 \%$, Alfa-Aesar), 在 $\mathrm{N}_{2}$ 气氛下, 从室温以 $1^{\circ} \mathrm{C} / \mathrm{min}$ 升温到 350 ${ }^{\circ} \mathrm{C}$, 恒温 $3 \mathrm{~h}$, 再经 $40 \mathrm{~min}$ 升到 $390^{\circ} \mathrm{C}$ 恒温 $4 \mathrm{~h}$, 再经 $160 \mathrm{~min}$ 升到 $550{ }^{\circ} \mathrm{C}$ 恒温 $4 \mathrm{~h}$, 最后自然冷却至室温, 收集所得的 黄色固体即为 $\mathrm{C}_{3} \mathrm{~N}_{4}$.

在制备 $\mathrm{AB}$ 和 $\mathrm{LiBH}_{4}$ 改性的 $\mathrm{C}_{3} \mathrm{~N}_{4}$ 复合体系时, 首先分 别称取 $123 \mathrm{mg}$ 的 $\mathrm{LiBH}_{4}$ 和1.23 g的 $\mathrm{C}_{3} \mathrm{~N}_{4}$, 在Retsch PM400 型行星式球磨机上球磨 $5 \mathrm{~h}(200 \mathrm{r} / \mathrm{min})$, 所得混合物在 $\mathrm{Ar}$ 气氛中于 $300{ }^{\circ} \mathrm{C}$ 焙烧 $2 \mathrm{~h}$, 所得产物为 $\mathrm{LiBH}_{4}$ 改性的 $\mathrm{C}_{3} \mathrm{~N}_{4}$, 记为 $\mathrm{LC}_{3} \mathrm{~N}_{4}$. 然后, 分别称取质量比 $(x: y)$ 为 $2: 1,1: 1$ 及 $1: 2$ 的 $\mathrm{AB}$ 和 $\mathrm{LC}_{3} \mathrm{~N}_{4}$, 球磨 $24 \mathrm{~h}$ 即得到三种不同比例的 $\mathrm{AB}-\mathrm{LC}_{3} \mathrm{~N}_{4}$ 样品, 记为 $x \mathrm{AB}-y \mathrm{LC}_{3} \mathrm{~N}_{4}$.

\section{2. $A B, C_{3} N_{4}$ 及 $x A B-y L C_{3} N_{4}$ 的放氢性能测试}

$\mathrm{AB}$ 及 $x \mathrm{AB}-y \mathrm{LC}_{3} \mathrm{~N}_{4}$ 的程序升温脱附-质谱(TPD-MS) 联用实验在自行安装的装置上进行, 样品由室温以 2 ${ }^{\circ} \mathrm{C} / \mathrm{min}$ 升至 $400{ }^{\circ} \mathrm{C}$, 载气为高纯 $\mathrm{Ar}$. 采用 $\mathrm{MS}$ 在线检测 $\mathrm{AB}$ 及 $x \mathrm{AB}-y \mathrm{LC}_{3} \mathrm{~N}_{4}$ 脱氢后的气体产物.

$A B$ 及 $x A B-y L_{3} \mathrm{~N}_{4}$ 的放氢量测试在自行安装的装置 上进行. 在手套箱中将一定量的 $A B$ 或 $x A B-y L C_{3} \mathrm{~N}_{4}$ 装填 在反应管底部, 将反应管密封后放入预先升至 $75^{\circ} \mathrm{C}$ 的加 热炉中, 同时开启压力传感器, 监测放氢过程. 根据理想 气体方程计算放氢量.

放氢结束后, 将气体缓慢导入配制的稀硫酸溶液中, 通过记录稀硫酸溶液的电导率变化及导入气体的量, 即 可计算得出所产生气体中的 $\mathrm{NH}_{3}$ 浓度.

\section{3. $\mathrm{AB}, \mathrm{C}_{3} \mathrm{~N}_{4}$ 及 $x \mathrm{AB}-y \mathrm{LC} \mathrm{C}_{3} \mathrm{~N}_{4}$ 的表征}

$\mathrm{AB}, \mathrm{C}_{3} \mathrm{~N}_{4}$ 及 $x \mathrm{AB}-y \mathrm{LC}_{3} \mathrm{~N}_{4}$ 样品的晶相结构在 PANalytical型 X射线衍射(XRD)仪上测定, 使用 $\mathrm{Ni}$ 过滤 
的 $\mathrm{Cu} K_{\alpha}$ 射线, 管电压 $40 \mathrm{kV}$, 管电流 $40 \mathrm{~mA}$, 扫描范围 $5^{\circ} \sim 80^{\circ}$. 热重 - 差热 (TG-DTA) 分析在 Netzsch 公司的 STA449C型热分析仪器上进行, 从室温以 $2^{\circ} \mathrm{C} / \mathrm{min}$ 升至 $400^{\circ} \mathrm{C}$, 载气为高纯 Ar. 魔角旋转核磁共振 (MAS NMR) 表征在Bruker公司Avance 500 型NMR仪器上进行, ${ }^{11} \mathrm{~B}$ 及 ${ }^{13} \mathrm{C}$ 均在 11.7 T磁场强度下测量, 此时 ${ }^{11} \mathrm{~B}$ 及 ${ }^{13} \mathrm{C}$ 的核磁共 振频率分别为 160.5 和 $125.76 \mathrm{MHz}$, 定标参照物分别为 $\mathrm{LiBH}_{4}$ 和甘氨酸.

\section{3. 结果与讨论}

\section{1. 放氢性能测试及表征}

首先将合成的 $\mathrm{AB}$ 和 $\mathrm{C}_{3} \mathrm{~N}_{4}$ 按照质量比 $1: 1$ 的比例球 磨, 试图对 $\mathrm{AB}$ 进行改性. 图 1 为 $\mathrm{AB}$ 和 $\mathrm{AB}-\mathrm{C}_{3} \mathrm{~N}_{4}$ 的 TPD-MS谱. 可以看出, $\mathrm{AB}$ 从室温到 $250^{\circ} \mathrm{C}$ 之间分两步 进行放氢, 分别在 112 和 $160^{\circ} \mathrm{C}$, 与文献 ${ }^{[4,5]}$ 结果一致; 经 $\mathrm{C}_{3} \mathrm{~N}_{4}$ 修饰后, $\mathrm{AB}$ 第一步放氢温度降至 $105^{\circ} \mathrm{C}$, 表明 $\mathrm{C}_{3} \mathrm{~N}_{4}$ 的加入对 $\mathrm{AB}$ 放氢有明显的促进作用. 第二步放氢呈现 宽化现象, 峰温约为 $152{ }^{\circ} \mathrm{C}$. 这可能是由于 $\mathrm{C}_{3} \mathrm{~N}_{4}$ 的加入 使 $\mathrm{AB}$ 第一步分解产生了不同的分解产物, 导致第二步 脱氢峰宽化. 值得一提的是, $\mathrm{C}_{3} \mathrm{~N}_{4}$ 的加入明显抑制了对 燃料电池有毒害作用的副产物无机苯的生成; 但另外一 种副产物 $\mathrm{NH}_{3}$ 的含量明显升高, 这可能是因为所合成的 $\mathrm{C}_{3} \mathrm{~N}_{4}$ 中含有一定量的 $-\mathrm{NH}_{2}$ 或- $\mathrm{NH}$ 基团, 在与 $\mathrm{AB}$ 作用时 取代了 $\mathrm{AB}$ 中的 $\mathrm{NH}_{3}$ 造成的. 所合成的 $\mathrm{C}_{3} \mathrm{~N}_{4}$ 的元素分析 表明, 其组成为 $\mathrm{C}_{3} \mathrm{~N}_{5.4} \mathrm{H}_{0.2}$; 同时该样品的FT-IR谱中于 $3070 ~ 3310 \mathrm{~cm}^{-1}$ 处出现 $\mathrm{N}-\mathrm{H}$ 振动峰, 进一步证实 $-\mathrm{NH}_{2}$ 或 $-\mathrm{NH}$ 基团的存在.

研究表明, 氢化物、硼氢化物等可以同氨基化合物 相互作用, 从而减少氨基化合物分解过程中氨的生 成 ${ }^{[3,16]}$. 为了降低气体产物中的氨浓度, 我们首先利用 $\mathrm{LiBH}_{4}$ 修饰 $\mathrm{C}_{3} \mathrm{~N}_{4}$ 合成 $\mathrm{LC}_{3} \mathrm{~N}_{4}$, 再将后者与 $\mathrm{AB}$ 进行球磨复 合, 合成了三个比例的 $x \mathrm{AB}-y \mathrm{LC}_{3} \mathrm{~N}_{4}$ 体系. 其中 $\mathrm{AB}$ 与 $\mathrm{LC}_{3} \mathrm{~N}_{4}$ 的质量比分别为 $2: 1,1: 1$ 及 $1: 2$, 以下分别简写为 $2 \mathrm{AB}-1 \mathrm{LC}_{3} \mathrm{~N}_{4}, 1 \mathrm{AB}-1 \mathrm{LC}_{3} \mathrm{~N}_{4}$ 和 $1 \mathrm{AB}-2 \mathrm{LC}_{3} \mathrm{~N}_{4}$.

图 2 为所合成样品的 XRD 谱. 可以看出, $\mathrm{C}_{3} \mathrm{~N}_{4}$ 在 $13.2^{\circ}$ 出现一个弱峰, 其最强的衍射峰在 $27.2^{\circ}$, 与文献报 道的 $g-\mathrm{C}_{3} \mathrm{~N}_{4}(002)$ 晶面的衍射峰吻合 ${ }^{[17]}$. $1 \mathrm{AB}-1 \mathrm{LC}_{3} \mathrm{~N}_{4}$ 和 $2 \mathrm{AB}-1 \mathrm{LC}_{3} \mathrm{~N}_{4}$ 两个样品都出现了与 $\mathrm{AB}$ 相同位置的衍射 峰, 说明 $\mathrm{AB}$ 存在于球磨后的复合体系中. 但是随着 $\mathrm{AB}$ 比例的减小, 其衍射峰也逐渐变弱. 有趣的是, 将 $\mathrm{AB}$ 与 $\mathrm{LC}_{3} \mathrm{~N}_{4}$ 的质量比为 $1: 2$ 的样品进行球磨时, 约有 1.2 equiv. 气体/AB释放出来, 经过质谱分析发现, 气体主要为 $\mathrm{H}_{2}$ 以
及少量的 $\mathrm{B}_{2} \mathrm{H}_{6}$. 这种现象在其它两个样品中并未观察 到. XRD结果发现, $1 \mathrm{AB}-2 \mathrm{LC}_{3} \mathrm{~N}_{4}$ 样品的衍射峰完全消失, 呈无定形状态.

之后我们对所合成的样品进行了脱氢性能考察, 图 3 为它们的 TPD-MS 谱. 可以看出, $A B, 2 A B-1 L_{3} \mathrm{~N}_{4}$ 及 $1 \mathrm{AB}-1 \mathrm{LC}_{3} \mathrm{~N}_{4}$ 三种样品第一步放氢温度分别为 112,105 及 $101{ }^{\circ} \mathrm{C}$, 即随着 $\mathrm{LC}_{3} \mathrm{~N}_{4}$ 掺杂量增加, $\mathrm{AB}$ 放氢温度降低. 经 $\mathrm{LiBH}_{4}$ 修饰后, $\mathrm{C}_{3} \mathrm{~N}_{4}$ 对 $\mathrm{AB}$ 脱氢的促进作用增大. 需要 指出的是, $\mathrm{LC}_{3} \mathrm{~N}_{4}$ 的加入同样抑制了无机苯的生成. 对 于 $1 \mathrm{AB}-2 \mathrm{LC}_{3} \mathrm{~N}_{4}$ 体系, 第一步放氢峰几乎消失, 这与球磨 过程中释放 $\mathrm{H}_{2}$ 相关. 更重要的是, $1 \mathrm{AB}-1 \mathrm{LC}_{3} \mathrm{~N}_{4}$ 和 $2 \mathrm{AB}-1 \mathrm{LC}_{3} \mathrm{~N}_{4}$ 样品在分解放氢过程中的氨信号均明显低 于 $\mathrm{AB}-\mathrm{C}_{3} \mathrm{~N}_{4}$.

为了确定各个样品的放氢量, $75^{\circ} \mathrm{C}$ 时采用体积法测 试了放氢性能, 结果见图 4. 可以看出, $75^{\circ} \mathrm{C}$ 时 $\mathrm{AB}$ 分解 存在诱导期, 并最终在 $12 \mathrm{~h}$ 内释放出 0.9 equiv. $\mathrm{H}_{2} / \mathrm{AB}$, 与 文献报道的 $\mathrm{NH}_{3} \mathrm{BH}_{2} \mathrm{NH}_{3} \mathrm{BH}_{4}(\mathrm{DADB})$ 诱发氨硼烷分解情 况基本吻合 ${ }^{[18]}$. 由于 $1 \mathrm{AB}-2 \mathrm{LC}_{3} \mathrm{~N}_{4}$ 体系在球磨过程中已 放出了 $\mathrm{H}_{2}$, 所以在 $75^{\circ} \mathrm{C}$ 放氢性能测试中只检测到少量 $\mathrm{H}_{2}$ 的生成. $1 \mathrm{AB}-1 \mathrm{LC}_{3} \mathrm{~N}_{4}$ 和 $2 \mathrm{AB}-1 \mathrm{LC}_{3} \mathrm{~N}_{4}$ 两个体系在放氢 时诱导期及放氢时间均显著缩短: 当释放 0.6 equiv. $\mathrm{H}_{2} / \mathrm{AB}$ 时, $\mathrm{AB}$ 需 $5.6 \mathrm{~h}$, 而 $1 \mathrm{AB}-1 \mathrm{LC}_{3} \mathrm{~N}_{4}$ 和 $2 \mathrm{AB}-1 \mathrm{LC}_{3} \mathrm{~N}_{4}$ 两 个体系分别只需要 4.5 和 $3.4 \mathrm{~h}$. 虽然 $\mathrm{LC}_{3} \mathrm{~N}_{4}$ 有效地缩短了 $\mathrm{AB}$ 放氢的诱导期, 但是 $x \mathrm{AB}-y \mathrm{LC}_{3} \mathrm{~N}_{4}$ 的放氢仍然为一个 $\mathrm{S}$ 型曲线. 这说明 $x \mathrm{AB}-y \mathrm{LC}_{3} \mathrm{~N}_{4}$ 体系分解放氢似乎依然遵 循着 $\mathrm{AB}$ 自分解放氢过程中DADB诱导机理. 另外, 如表 所示, $1 \mathrm{AB}-1 \mathrm{LC}_{3} \mathrm{~N}_{4}$ 和 $2 \mathrm{AB}-1 \mathrm{LC}_{3} \mathrm{~N}_{4}$ 两个体系中 $\mathrm{NH}_{3}$ 浓度 分别为 $1.13 \%$ 和 $2.59 \%$, 略高于 $\mathrm{AB}$ 体系, 但明显低于 $\mathrm{AB}-\mathrm{C}_{3} \mathrm{~N}_{4}$ 体系.

样品的TG-DTA曲线见图5. 可以看出, AB的第一 个吸热峰为 $\mathrm{AB}$ 熔化所致, 第二个放热峰归属为 $\mathrm{AB}$ 脱氢 放热, 脱氢峰温为 $109{ }^{\circ} \mathrm{C}$, 与 $\mathrm{TPD}$ 结果基本吻合. 加热到 $180{ }^{\circ} \mathrm{C}$ 时 $\mathrm{AB}$ 失重约为 $49.1 \%$, 而 $2 \mathrm{AB}-1 \mathrm{LC}_{3} \mathrm{~N}_{4}$ 和 $1 \mathrm{AB}-1 \mathrm{LC}_{3} \mathrm{~N}_{4}$ 分别约为 $20.1 \%$ 和 $11.9 \%$, 若按照 $\mathrm{AB}$ 计算, 失重量分别为 $30.1 \%$ 和 $23.8 \%$. 这表明 $\mathrm{LC}_{3} \mathrm{~N}_{4}$ 的掺杂使得 $x \mathrm{AB}-y \mathrm{LC}_{3} \mathrm{~N}_{4}$ 生成了较多的 $\mathrm{NH}_{3}$, 但明显抑制了其它副产 物 (如挥发性的无机苯) 的生成. 值得注意的是, $2 \mathrm{AB}-1 \mathrm{LC}_{3} \mathrm{~N}_{4}$ 和 $1 \mathrm{AB}-1 \mathrm{LC}_{3} \mathrm{~N}_{4}$ 两个体系中未出现 $\mathrm{AB}$ 熔化 吸热峰. 这可能是因为 $L_{3} \mathrm{~N}_{4}$ 的加入降低了 $\mathrm{AB}$ 的放氢温 度, 使其在低于其熔点下分解放氢, 从而破坏了 $\mathrm{AB}$ 的晶 体结构所致.

由于 $\mathrm{AB}$ 放氢分解后生成无定形产物, 其XRD谱不 
能给出有关结构的信息, 因此本文试图利用NMR技术对 $\mathrm{AB}$ 及修饰后的 $\mathrm{AB}$ 进行表征. 图6和图7分别是各样品在 分解前后的 ${ }^{11} \mathrm{~B}$ 和 ${ }^{13} \mathrm{C}$ MAS NMR谱. 如图6所示, $\delta=$ -26.7 处的峰是 $\mathrm{AB}$ 中 $\mathrm{BH}_{3}$ 特征峰, 与文献报道 ${ }^{[19]}$ 相近. $\mathrm{LiBH}_{4}$ 修饰后的 $\mathrm{C}_{3} \mathrm{~N}_{4}$ 在 16.9 和 -0.4 出现两个B物种峰, 前 者应归属为 $s p^{2}$ 杂化的 $\mathrm{BN}_{3}$ 或 $\mathrm{BN}_{2} \mathrm{H}$ 物种，而后者可能是 $\mathrm{LiBH}_{4}$ 同 $\mathrm{C}_{3} \mathrm{~N}_{4}$ 相互作用形成的 N-B-C物种. 在球磨后的 $2 \mathrm{AB}-1 \mathrm{LC}_{3} \mathrm{~N}_{4}$ 和 $1 \mathrm{AB}-1 \mathrm{LC}_{3} \mathrm{~N}_{4}$ 体系中除了仍保留的 $\mathrm{BH}_{3}$ 特 征峰外, 还检测到 $\mathrm{BH}_{4}{ }^{-}$特征峰(-41.5), 它可能为 $\mathrm{LC}_{3} \mathrm{~N}_{4}$ 诱 导 $\mathrm{AB}$ 作用产生的 $\mathrm{BH}_{4}$ 物种. $\mathrm{AB}$ 在 $75^{\circ} \mathrm{C}$ 放氢后仍然有残 留的少量 $\mathrm{BH}_{3}$, 同时在 -36.5 和 -10.1 处分别产生了新的 $\mathrm{BH}_{4}$ 和 $\mathrm{BH}_{2}$ 特征峰, 这归因于 $\mathrm{AB}$ 自分解过程中产生的 $\mathrm{DADB}^{[20]}$. 值得注意的是, 如图6所示, $\mathrm{AB}$ 放氢生成的 $\mathrm{BH}_{4}$ 物 种在 -36.5 附近，不同于 $2 \mathrm{AB}-1 \mathrm{LC}_{3} \mathrm{~N}_{4}$ 和 $1 \mathrm{AB}-1 \mathrm{LC}_{3} \mathrm{~N}_{4}$ 体系。在 $2 \mathrm{AB}-1 \mathrm{LC}_{3} \mathrm{~N}_{4} 75^{\circ} \mathrm{C}$ 放氢后, 于 $-22.2,-40.4$ 和 -35.5 处出现特征峰, 分别归属为剩余的 $\mathrm{BH}_{3}, \mathrm{LC}_{3} \mathrm{~N}_{4}$ 诱导 $\mathrm{AB}$ 产生的 $\mathrm{BH}_{4}$ 以及 $\mathrm{AB}$ 自分解新生成的 $\mathrm{BH}_{4}$. 而 $-26 \sim 30$ 的宽峰可能为 $\mathrm{BH}_{3}, \mathrm{BH}_{2}, \mathrm{BH}\left(s p^{3}\right)$, $\mathrm{BN}_{2} \mathrm{H}\left(s p^{2}\right)$ 或 $\mathrm{BN}_{3}\left(s p^{2}\right)$ 以及N-B-C物种的混合峰 ${ }^{[21]}$. 因为 $1 \mathrm{AB}-2 \mathrm{LC}_{3} \mathrm{~N}_{4}$ 体系在球磨过程中放氢, 所以该体系 $75^{\circ} \mathrm{C}$ 处理前后均得到了相似的谱图, 并且同 $1 \mathrm{AB}-1 \mathrm{LC}_{3} \mathrm{~N}_{4} 75$ ${ }^{\circ} \mathrm{C}$ 放氢后的基本相同, 即存在-40.3 $\left(\mathrm{BH}_{4}\right),-22.8\left(\mathrm{BH}_{3}\right)$, $-1.2(\mathrm{~N}-\mathrm{B}-\mathrm{C})$ 和17.8 $\left(\mathrm{BN}_{2} \mathrm{H}\right.$ 或 $\left.\mathrm{BN}_{3}\right)$. 此外, 这三条 NMR图 谱30 -30内都具有较高的基线. 这可能是因为样品中仍 然含有 $\mathrm{AB}$ 分解后产生的 $\mathrm{BH}$ 及 $\mathrm{BH}_{2}$ 物种. 由于在放氢产 物中观察到 $\mathrm{BH}_{4}$ 及 $\mathrm{BH}_{2}$ 物种, 可以推测 $x \mathrm{AB}-y \mathrm{LC}_{3} \mathrm{~N}_{4}$ 体系 在分解过程中仍然遵循DADB诱导机理. 这同前述的 $\mathrm{S}$ 型放氢曲线是一致的.

如图7所示, 所合成的 $\mathrm{C}_{3} \mathrm{~N}_{4}$ 有 $\mathrm{CN}_{2}\left(\mathrm{NH}_{2}\right)$ (环边界)和 $\mathrm{CN}_{3}$ (环内部)两种 $\mathrm{C}$ 的化学环境, 分别在 $\delta=157$ 和 165 具 有特征峰, 与文献 ${ }^{[21]}$ 结果相近. 在 $\mathrm{LC}_{3} \mathrm{~N}_{4}$ 中仍然存在着 这两种特征峰, 但是 157 附近的特征峰有所增强, 说明由 于 $\mathrm{LiBH}_{4}$ 的作用, $\mathrm{C}_{3} \mathrm{~N}_{4}$ 中边界的碳物种有所增加, 这可能 是由于部分 $\mathrm{C}_{3} \mathrm{~N}_{4}$ 稠环被 $\mathrm{LiBH}_{4}$ 分裂为单环. 同时 $\mathrm{LC}_{3} \mathrm{~N}_{4}$ 样品中生成 $\delta=23 \sim 83$ 处连续的几个特征峰, 可归属为碳 的 $s p^{3}$ 杂化物种. 这很有可能是由于 $\mathrm{C}_{3} \mathrm{~N}_{4}$ 的稠环被分裂 后, 碳元素再进一步加氢使得 $\mathrm{CN}_{3}\left(s p^{2}\right.$ 杂化)变成 $\mathrm{CN}_{3} \mathrm{H}$,
( $s p^{3}$ 杂化). 在 $2 \mathrm{AB}-1 \mathrm{LC}_{3} \mathrm{~N}_{4}, 1 \mathrm{AB}-1 \mathrm{LC}_{3} \mathrm{~N}_{4}$ 和 $1 \mathrm{AB}-2 \mathrm{LC}_{3} \mathrm{~N}_{4}$ 分解前后的样品中均存在着157和165的特征峰. 然而随 着脱氢的进行, 165附近的特征峰明显减弱, 而157附近 的特征峰增强. 这说明 $\mathrm{AB}$ 可以进一步使 $\mathrm{C}_{3} \mathrm{~N}_{4}$ 由稠环转 变为单环物种, 导致环边界的碳物种增多.

\section{2. 动力学测试}

为了得到 $\mathrm{AB}$ 及 $\mathrm{LC}_{3} \mathrm{~N}_{4}$ 掺杂的 $\mathrm{AB}$ 的脱氢反应动力学 数据, 本文在不同升温速率 $\left(0.5,1,2\right.$ 和 $\left.3^{\circ} \mathrm{C} / \mathrm{min}\right)$ 下进行 了DTA分析, 以得到反应速率最大值的温度, 然后根据 Kissinger 方程 (见式 (1)) 来确定 $\mathrm{AB}, 1 \mathrm{AB}-1 \mathrm{LC}_{3} \mathrm{~N}_{4}$ 和 $2 \mathrm{AB}-1 \mathrm{LC}_{3} \mathrm{~N}_{4}$ 样品的表观活化能 $E_{\mathrm{a}}$ 和指前因子 $A$.

$$
\ln \left(\beta / T_{\mathrm{p}}^{2}\right)=\ln \left(A R / E_{\mathrm{a}}\right)-E_{\mathrm{a}} / R T_{\mathrm{p}}
$$

其中, $\beta, T_{\mathrm{p}}$ 和 $R$ 分别为升温速率、反应速率最大时的温度 和理想气体常数. 在较小的温度变化范围内, 可假定 $E_{\mathrm{a}}$ 和 $A$ 为恒量, 以 $\ln \left(\beta / T_{\mathrm{p}}^{2}\right.$ )对 $1 / T_{\mathrm{p}}$ 作图 (见图8), 拟合可以得 到一条直线, 其斜率为 $-E_{\mathrm{a}} / R$, 截距为 $\ln \left(A R / E_{\mathrm{a}}\right)$, 从而得到 $E_{\mathrm{a}}$ 和 $A$, 然后根据阿伦尼乌斯方程(见式(2))可计算某一 温度下的反应速率常数 $k$.

$$
k=A \exp \left(-E_{\mathrm{a}} / R T\right)
$$

表2归纳了各样品的 $E_{\mathrm{a}}, A$ 和 $k$ 值 $\left(75^{\circ} \mathrm{C}\right)$. 可以看出, 第一步热分解反应的 $E_{\mathrm{a}}$ 基本没有变化。这说明 $x \mathrm{AB}-y \mathrm{LC}_{3} \mathrm{~N}_{4}$ 分解机理可能依然遵循着 $\mathrm{AB}$ 自分解放氢机 理, 与放氢曲线和 $N M R$ 结果一致. 可见 $L_{3} \mathrm{~N}_{4}$ 的加入可 以诱导 $\mathrm{AB}$ 低温下快速产生 $\mathrm{DADB}$, 并进一步诱导 $\mathrm{AB}$ 分 解, 从而缩短了 $\mathrm{AB}$ 分解的诱导期. 由阿伦尼乌斯方程算 得 $75{ }^{\circ} \mathrm{C}$ 时 $2 \mathrm{AB}-1 \mathrm{LC}_{3} \mathrm{~N}_{4}$ 和 $1 \mathrm{AB}-1 \mathrm{LC}_{3} \mathrm{~N}_{4}$ 样品的第一步脱 氢反应速率常数分别是 $\mathrm{AB}$ 脱氢的 1.8 和 2.3 倍, 放氢反应 速率明显加快.

\section{4. 结论}

利用 $\mathrm{LiBH}_{4}$ 对自行合成的 $\mathrm{C}_{3} \mathrm{~N}_{4}$ 进行改性得到 $\mathrm{LC}_{3} \mathrm{~N}_{4}$, 再利用 $\mathrm{LC}_{3} \mathrm{~N}_{4}$ 修饰氨嗍烷, 得到了放氢性能优异的材料, 这为改善氨嗍烷放氢性能提供了一个新的思路. 然而修 饰后的氨硼烷放氢过程中有大量副产物 $\mathrm{NH}_{3}$ 生成, 可通 过优化 $\mathrm{C}_{3} \mathrm{~N}_{4}$ 合成方法, 提高 $\mathrm{C}_{3} \mathrm{~N}_{4}$ 的聚合度, 以减少 $\mathrm{C}_{3} \mathrm{~N}_{4}$ 中氨基的数量, 或添加其它种类的材料, 来屏蔽 $\mathrm{C}_{3} \mathrm{~N}_{4}$ 中 的氨基基团, 从而抑制氨嗍烷分解放氢过程中氨气. 